\title{
The Role of Private Law in the Regulation of Educational Relations
}

\author{
Elena Vasilievna Kobchikova ${ }^{1} \&$ Timofey Grigorievich Makarov ${ }^{1}$ \\ ${ }^{1}$ Kazan Federal University, Russia \\ Correspondence: Elena Vasilievna Kobchikova, Kazan Federal University, Russia. E-mail: mix-les@mail.ru
}

Received: June 9, 2019

Accepted: August 25, $2019 \quad$ Online Published: August 31, 2019

doi:10.5539/jpl.v12n5p20

URL: https://doi.org/10.5539/jpl.v12n5p20

\begin{abstract}
In this article prepared by Kobchikova E.V. and Makarov T.G., the connection between private law with educational relations is considered; it is stated that educational relations are characterized by the presence of public and private components in them. The work gives a detailed description to civil relations in the sphere of education, explores the concept of educational service, and considers the place of an agreement for rendering paid educational services among other service agreements. The authors of the article note that this agreement, just like the majority of civil law contracts, is a bilaterally binding one, i.e., both parties (educational institution and student) are bound with mutual obligations. In accordance with the principles of private law regulations, educational relations are regulated by the parties to the agreement for rendering fee-based educational services, based on the legal equality of the parties. Thus, the subjects of educational relations may create rights and obligations for themselves, as well as to change and terminate them. The authors note that agreements in the sphere of professional education allow students developing independence in learning, thus letting them controlling their educational experience in accordance with their needs and interests. All this points to the significant role of private law in the regulation of educational relations.
\end{abstract}

Keywords: private law, civil relations, educational relations, educational institution, agreement, public law

\section{Introduction}

In the Russian Federation, the state of the art of domestic education influences both state social policy and national strategy of economic development. Currently, the level of quality of education services rendered affects most aspects of social life. Article 43 of the Constitution of the Russian Federation establishes the right of each citizen on education. Federal law "On education in the Russian Federation" defines education as a "unified goal-oriented process of upbringing and learning, which forms a socially significant good".

Successful preparation and effective introduction of the aimed programs in the sphere of general education at the account of budgetary funds, realization of the exact sum that fully coincides with the one mentioned in the program, as well as the provision of a peer review of the performance indicators may enhance the effectiveness of achieving an optimal quality of education in educational establishments across the country. Professional education in Russia is characterized by a difficult and quite long-lasting adaptation of graduate students in the labor market and significant investments of private companies into vocational retraining of graduates and their additional training. The presence of these problems indicates the need of the professional labor market to have an effective regulation within the scope of private law because a person is a part that requires a quality professional education.

Consequently, the existing problems of the modern educational sphere allow concluding that the actual mechanism of the state regulation has its drawbacks that cause a negative impact on the development of personalities and human capacity of the state.

The development of education in Russia is conditioned by the prospective quality changes in society. Informational technologies, global computerization, and telecommunication are changing the world, and this defines the need in the reorganization of existing educational technologies. However, the dynamic development of education is not possible without a relevant legal regulation within the sphere of private law. This is the reason that conditions the interest to legal problems that are associated with the reformation of education at all levels, which, as should be noted, has been in progress during the recent years. 


\section{Methods}

The key methods that allow exploring the role of private law in the regulation of educational relations are the dialectic method and inter-sectorial method of legal researches. The dialectic method allows understanding the connection between the processes related to the regimentation within the educational activity. The inter-sectoral method allows combining civil, administrative and other means in the regulation of educational relations.

\section{Results and Discussion}

The conjunction of public and private components in legal relations related to the provision of educational services forms their peculiarities. In this connection, the opinion of I.A. Pokrovsky is worth attention, who stated that there is no "strict demarcation line" between private and public law. During the Soviet period, legal relations connected with the rendering of educational services were fully subjected to the sphere of public law; however, after the breakup of the Soviet Union, revolutionary changes in all social spheres took place, which conditioned the transition of the state to the market economy. The acceptance of private property and leveling of all its forms introduced a private component into the educational system. If public law is a subordination system, then private law is a coordination system; if the first notion relates to the sphere of power and submission, then the second one relates to the sphere of freedom and private initiative.

At his time, an outstanding Soviet and American legal expert O.S. Ioffe noted that the problem of legal relations is one of the most difficult and, at the same time, less developed in the legal science. There are both objective and subjective reasons for disputes, the most part of which is conditioned by historical changes in the development of legal relations. Thus, V.M. Sirykh, one of the Russian advocates of the theory of educational right, thinks that educational relations are not regulated by civil rights, and educational agreement appears to be a quasi-document in reality. That is why he thinks that educational relations are a special type of legal relations that differs from civil, administrative and any other types of legal relations. The same opinion is supported by the researcher V.A. Belov.

In his turn, E.A. Sukhanov defines educational relations as a sort of administrative relations, and this opinion also cannot be admitted because the stated relations lack state coercion that is typical for administrative law, and not all the relations fall within the scope of administrative law.

Today, the large part of educational relations are characterized by a public right charter; however, the procedure of their legal regulatory activity should also include elements of public law regulation. In the sphere of education, the border between the private and the public is not permanent and it depends on the value given to education by the state. Transition to market economy conditioned the distribution of private segment in the sphere of education and formed the market of educational services. Educational institutions obtained significant powers in the sphere of private law, which are actively used today.

Further characteristics of civil relations in the sphere of education require the definition of the type of legal relations they refer to. O.S. Ioffe stated that legal relations can be divided into the property and non-property ones. However, the Soviet epoch is gone, and later E.A. Sukhanov expressed the opinion that "property and liability rights comprise one of the essential bases of civil law regulation". In his turn, V.A. Belov and A.B. Babaev suppose that the most significant place belongs to the group of absolute and relative legal relations that are defined according to the criterion of the obligatory subjects - in absolute relations the latter is not defined while in the relative ones it is defined.

Property and obligations relations are the forms of absolute and relative ones, because the liability right as a type of relative rights is referred to its content (the demand for a certain action), while the property right - as a kind of absolute rights - is referred to its object (an individually defined thing). Also, it is worth noting that legal relations are divided into regulative and protective ones.

Consequently, when speaking about legal relations in the context of educational sphere, one may refer to the presence of relative relations, because they imply the definite character of a subjective content both at empowered and obliging parties. Legal powers are distributed between these parties, which defines the specific character of these subjects.

While giving examples of various scientific paradigms, it is necessary to draw one's attention to the dynamics of the changes of legal relations' content that depend on such aspects as the level of social or state development, condition of scientific and technological progress, actual social needs and other socially significant problems of educational service.

Educational service does not have an embodied result; it is evidenced in the knowledge, skills, and expertise acquired by the consumer during the rendering of the service. Getting a diploma or other educational certificate cannot be considered as an embodied result; it only gives information about achieving this or that academic degree. 
Also, it is worth noting that the obliged party does not give any warranties regarding the expected result since the latter one is beyond the agreement, the subject of which is the activity itself, but not the result of this activity. Besides, the result of educational services is directly connected with the personal qualities of a consumer of the service.

Thus, it should be noted that civil relations in the sphere of education are relative ones and are characterized by the long-lasting nature of the subjects' cooperation, which is conditioned by the term of education, combination of public and private interests, and also the presence of a certain level of intellectual development in its subjects.

When turning to the consideration of the essence of private law in the sphere of education, it should be noted that they relate to the group of actual services. The legal notion of an educational service may be formulated based on economic and pedagogic content of educational process. At the same time, all educational services may be subdivided into educational services generally and properly. The base of such a distribution consists of the personality of a contractor, the volume and scope of service, the peculiarities of the rendering procedure, and the peculiarities of formalization of the achieved result. The process of getting education directly depends on the definition of educational service in its limited context.

The objects of civil rights should include such services that, first of all, satisfy the private interests of a person. This fact conditions the necessity in regulating the relations that touch on the rendering of such services through the norms of the law in the sphere of education and civil legislation within the scope of private rights. Other educational services, such as proper education services that are financed at the account of budget funds, will satisfy both private and state interests. This fact conditions the regulation activities towards rendering of such services exclusively through the norms of the law on education.

While considering the place of an agreement for rendering paid educational services among other service provision agreements, it can be noted that it ranks among the agreements for rendering actual services. This fact differs such agreement from the dealings that form the group of agreements for rendering legal services and dealings that combine the fulfillment of actual and legal actions. The peculiarities of the dealing allow distinguishing it from other agreements for rendering actual services, including the ones that are similar in their content - particularly, consulting agreements or agreements for rendering informational services.

It should be noted that agreements in the sphere of professional education help students develop independence in their learning process, thus allowing them to control their academic expertise in accordance with their needs and interests. The application of the mentioned agreements, by all means, causes a certain impact on the development of competences that relate to independent education.

An agreement for rendering paid educational services, just like the majority of other civil law agreements, is a bilaterally binding one. It means that all its parties (an educational institution and a student) are bound with each other with mutual obligations. The agreement is concluded by means of forwarding an offer to a potential counteragent and accepting of this offer by the latter. An agreement will not be considered concluded in case an offeror does not receive an acceptation. In the case of concluding the agreement for rendering paid educational services, two options are possible. If an offeror is a contractor, then the agreement will be concluded according to the general rules stipulated by the Civil Code of the Russian Federation. The case when an educational establishment provides an offer would cover the organization of paid training courses, seminars, lectures, etc. The proposal to conclude an agreement, in this case, will be subject to the rules about public offers. The conclusion of an agreement will be accomplished by means of joining to pre-established conditions.

While considering the rights and obligations of a client, it should be noted that his/her main responsibilities would be to pay for the service and personally participate in the service's consumption. At the same time, it is very important to establish the procedure, means and deadlines for making such payments, and also to agree about the bases and procedures of changing the agreement price. In particular, it is important to notify the other party about a price increase not later than one semester prior to the price increase. The client has a right to demand the performance of one's respective obligations.

While considering the forms of obligations, it should be noted that the compensation of losses is its main form. Apart from compensating losses, the agreement in question may touch upon the payment of a penalty. The necessity of application of the rules about the penalty is necessary in all cases, even if it is difficult to define the level of a loss. At the same time, the penalty that is applied to the contractor of the agreement should be punitive, which will provide additional protection of rights of educational service users.

It should be noted that within the scope of the provision of private rights in the sphere of education, there is a problem of cooperation between the state and the society in the period of educational reformation, which is 
connected with the society's increased interest to innovational processes in education and with the aspiration of the large part of the society to practically participate in regulation and control of education. The current situation with managing education does not fully allow society and particular citizens participate in the adoption of managerial decisions in this sphere. Well-coordinated cooperation of the state and the society should form the basis for the development of private regulation of relations in the sphere of education.

\section{Conclusion}

It can be concluded that education is gaining a special value in the context of the establishment of the intellectual economy. In conditions of the market economy, the mechanism of educational system's function has been transforming. Thus, new funding sources occur, private and paid education appear to be more and more popular, and the process of managing education is changing. The modern logic of social development proves that the responsibility for education should be distributed among many different subjects. At the same time, the educational system should be more open, flexible and adapted to the new and constantly changing demands of the society.

In this work, the presence of private relations referring to the rendering of paid educational services was stated; the notion and content of a paid educational service as an object of civil law was defined; the general legal characteristics of such service was provided.

\section{Summary}

The regulation of educational system forms a peculiar economic behavior of a state in relation to educational institutions. The aim of the regulation of educational relations is the creation of conditions for an effective economic functioning of educational institutions, which would favor the achievement of these of those results, The role of the state in the regulation of educational system lies in the necessity to define the results of education, which the state and the society would like to achieve. However, it should also be taken into account that particular economic subjects also have a right to manage the educational process; that is why the state should not only be a guarantor of the citizens' rights to receive education, but also to be a guarantor of the private right in the sphere of education. This is in the first turn conditioned by the necessity to provide the citizens with more relevant information regarding the quality and accessibility of educational services for each citizen. An essential part in private law regulations should be played by the economic methods that both directly and indirectly influence the functioning of educational system.

\section{Acknowledgements}

The work is performed according to the Russian Government Program of Competitive Growth of Kazan Federal University.

\section{References}

Belov V. A. (Ed.). (2014). Civil law. Vol. 2. General part. Persons, goods, facts: the manual for bachelors V. A. Belov. M: Yurait Publishing house.

Belov, V. A. (Ed.). (2015). Civil law: actual problems of theory and practice under the general editorship of V. A. Belov. M.: Yurait Publishing house.

Caffarella, R. S., \& Caffarella, E. P. (1986). Self-directedness and learning contracts in adult education. Adult Education Quarterly, 36, 226-234. https://doi.org/10.1177/0001848186036004004

Civil law. In 4 volumes. Volume 2. Under the editorship pf E.A. Sukhanov. Moscow, 2014. 496 p.

Civil law: The manual in 2 volumes. Under the editorship of B.M. Gongalo. Vol.2 M.: Statut, 2017. 654 p.

Clarke, M. (2016). English Insurance Contract Law. Bookboon, Cambridge University.

Field, S. (2016). Introduction to the Law of Contract: Formation of a Contract. University of Brighton, Brighton Business School.

Ioffe, O. S. (1949). Legal relations in the Soviet civil law. O.S. Ioffe. L.: LSU publishing house.

Ioffe, O. S. (2014). The selected works: in 4 volumes. O.S. Ioffe. St-Petersburg.: Legal center Press.

Kozyrin, A. N., \& Troshkina, T. A. (2017) The Law on Education of 2012 and Development of Educational Law in Russia. Law. Higher School of Economics Journal, (1), 80-91. https://doi.org/10.17323/2072-8166.2017.1.80.91

McAllister, M. (1996). Learning contracts: an Australian experience. Nurse Education Today, 16(3), 199-205. https://doi.org/10.1016/S0260-6917(96)80024-4 
Pokrovskiy, I. A. (n.d.). The main problems of civil law. I. A. Pokrovskiy.

Rossiyskaya Gazeta № 23, 06.02.1996, № 24, 07.02.1996, № 25, 08.02.1996, № 27, 10.02.1996.

Rossiyskaya Gazeta, № 238-239, 08.12.1994. The Civil Code gazette of the Russian Federation (part 2) dated 26.01.1996 № 14-Ф3 (the version dated 29.07.2018)

Sukhanov, E. A. (2016). Property rights and rights on noon-material objects. The bulletin of the Supreme Arbitration Court of the Russian Federation, (7), 16-31.

Syrykh, V. M. (2017). Educational services and educational legal relations: discussion views and actual content. The journal of the Russian law, (4), 69-78.

The Civil Code gazette of the Russian Federation (part 1) dated 30.11.1994 № 51-Ф3 (the version dated 03.08.2018).

The Constitution of the Russian Federation dated 12.12.1993. The official gazette of the Russian Federation, 04.08.2014, № 31, Article 4398.

The Federal Law dated 29.12.2012 № 273-Ф3 (the version dated 17.06.2019) “On education in the Russian Federation”. Rossiyskaya Gazeta, № 303, 31.12.2012.

\section{Copyrights}

Copyright for this article is retained by the author(s), with first publication rights granted to the journal.

This is an open-access article distributed under the terms and conditions of the Creative Commons Attribution license (http://creativecommons.org/licenses/by/4.0/). 